Бінецька Д. І.

\title{
ПСИХОЛОГО-ПЕДАГОГІЧНИЙ АНАЛІЗ ДІЯЛЬНОСТІ ВИКЛАДАЧА І СТУДЕНТА В ХОДІ РОЗВИТКУ ДОСЛІДНИЦЬКИХ УМІНЬ МАЙБУТНІХ УЧИТЕЛІВ ІНОЗЕМНОЇ МОВИ
}

У статті розглядаються особливості реалізаиії дослідницьких умінь в процесі підготовки майбутнього вчителя іноземної мови та основні ідеї проблемного навчання, методи й прийоми, організаційні форми та засоби доиільного використання навчальних проблемних ситуащій, постановки і вирімення навчальних проблем, способи пред'явлення їх викладачем, прийняття та вирімення студентами проблем. Доведено, щзо однією з необхідних умов ефективної реалізачії дослідницьких умінь у вищому навчальному закладі є співпрачя, співробітництво викладача та студентів. Різноманітні визначення поняття дослідницьких умінь зумовлюють й різну їх класифікацію. Рівень розвитку творчого потениіалу в кожного педагога свій. Цей факт виключає усереднення в освіті, обумовлює необхідність особистісно орієнтованого навчання, врахування специфіки професійної підготовки студентів, їх інтересів та потреб, здібностей та можливостей. Іноземна мова виступає як засіб комунікації, спілкування з представниками інших націй, отже в освіті продовжує розвиватися $i$ надалі культурологічний або інтеркультурний підхід у навчанні в рамках конщепциї "діалогу культур", з метою формування полімовної грамотності студентів.

Однією з головних иінностей майбутнього педагога стає творча активність, $а$, відповідно, найефективнішим методом формування досліднищьких умінь в студентів майбутніх учителів іноземної мови, на нашу думку, стає раціональне використання елементів проблемно-пошукового навчання у всіх формах вузівської навчальної роботи: лекціях, семінарах, практичних заняттях, педагогічній практичі, курсових і дипломних роботах та ін. Однією з умов формування дослідницьких умінь майбутніх учителів іноземних мов є наявність суб'єктсуб'єктної взаємодї. Така умова потребує постановки проблемного запитання у доступній формі.

Отже, для розвитку здатності майбутнього вчителя іноземної мови впроваджувати дослідницькі уміння у прочес навчання необхідно оновлювати не лише зміст навчальних програм з усіх дисииплін, а й методики їх викладання; наполегливо впроваджувати в навчальний процес дискусійну форму проведення практичних занять; передбачати для студентів самостійний пошук причинно-наслідкових зв'язків $i$ закономірностей суспільних прочесів та явищ; проводити творчі конкурси студентських робіт.

Ключові слова: дослідницькі уміння, проблемне навчання, проблема, задача, майбутній педагог, творча активність, методи, форми, прийоми.

Як зазначає С. Максименко [4, с. 49], процес фрормування умінь розпочинається з усвідомлення завдання та способів його виконання, чому передує пояснення та демонстрація прикладу виконання завдання викладачем. Дослідницькими уміннями неможливо оволодіти, не маючи зразка або прикладу вирішення проблеми. Таким прикладом для студентів гуманітарних спеціальностей (зокрема майбутніх учителів іноземної мови) може бути проблемний виклад знань, який студенти можуть спостерігати на лекції.

Однією із особливостей діяльності вчителя, на думку В. А. Сластьоніна, $є$ 
те, що педагогічна дія вчителя спочатку виступає в ролі пізнавальної задачі. Спираючись на вже наявні знання, він теоретично співвідносить засоби, предмет і очікуваний результат своєї дії. Оскільки реальний результат може відрізнятися від очікуваного, то із практичної дії задача знову переходить у пізнавальну форму. Тому, наголошує вчений, діяльність учителя $є$ не чим іншим, як процесом розв'язання нескінченної кількості задач різноманітних типів, класів та рівнів [6, с. 73]. Специфічною особливість педагогічних задач $\epsilon$ те, що їхнє рішення ніколи не знаходиться на поверхні. Досить часто вони потребують напруженої роботи думки, аналізу великої кількості фрактів, умов та обставин. Така діяльність, як свідчить досвід, викликає менше труднощів у студентів - майбутніх учителів фрізико-математичних спеціальностей у зв'язку із специфікою предметів, які вони вивчають і викликає значні труднощі у студентів гуманітарних спеціальностей, зокрема, у майбутніх учителів іноземних мов.

Дослідницькі уміння майбутнього вчителя іноземної мови не є сталим явищем, багажем, який людина носить все життя у незмінному вигляді. Вони змінюються, розвиваються, збагачуються і в цьому розумінні $є$ невичерпними. Цей фракт виключає усереднення в освіті, обумовлює необхідність особистісноорієнтованого навчання, врахування специфіки професійної підготовки студентів, їх інтересів та потреб, здібностей та можливостей.

Метою розвитку дослідницьких умінь $є$ засвоєння студентом - майбутнім учителем не лише системи знань з іноземної мови, а й самого шляху, процесу одержання певних результатів, оскільки це дуже необхідно для його професійного становлення. Основними характеристиками мислення, що розвивається при цьому науковці вважають чіткість, логічність, системність, послідовність, самостійність, гнучкість, сміливість, оригінальність. При цьому важливу роль відіграє пізнавальна самостійність студентів як здатність і потреба особистості бачити і вирішувати нові для себе проблемні завдання. Результатом такого підходу до вивчення іноземної мови стає формування творчого мислення особистості, основними елементами якого виступають: уміння аналізувати, порівнювати, узагальнювати, самостійно переносити знання у нову галузь, уміння бачити альтернативу рішень, уміння комбінувати раніше відомі й нові способи вирішення тих чи інших завдань.

Слід пам'ятати й про те, що формування будь-якої якості чи умінь ніколи, ні за яких обставин, ні в якій діяльності не відбувається під тиском чи примусом. Тому усі змістовні компоненти і форми педагогічної діяльності, спрямованої на фрормування дослідницьких умінь у майбутніх учителів іноземної мови мають відповідати принципам гуманної педагогіки, їх необхідно будувати на основі суб'єкт-суб'єктної взаємодії учасників навчального процесу, що дасть можливість створити доброзичливий психологічний клімат у ВНЗ, який позитивно впливатиме не лише на формування дослідницьких умінь, а й на розвиток інтелектуальних, професійно-трудових здібностей і соціальних якостей майбутнього фрахівця.

Цікаву думку стосовно важливості дослідницьких умінь для професійної діяльності вчителя висловив В.Загвязинський. Він відзначав, що бути педагогом-дослідником - означає вміти знаходити нове в педагогічних явищах, виявляти в них невідомі зв'язки й закономірності, що потребує передусім 
загальної культури та високої фахової підготовки, певного досвіду навчальновиховної роботи й спеціальних знань і вмінь, притаманних саме дослідницькій роботі. Зокрема, треба вміти спостерігати й аналізувати педагогічні явища; узагальнювати результати спостережень, виділивши найголовніше; за певними ознаками передбачати розвиток явищ у перспективі; поєднувати точний розрахунок з уявою й інтуїцією та багато іншого. Складність педагогічних явищ із незавершеністю їх логічного аналізу та недостатньою інформованістю про них, робить проблему наукового пошуку особливо актуальною [3].

Дослідницькі уміння майбутнього вчителя іноземних мов розглядаємо як складне психічне утворення (синтез дій інтелектуальних, практичних; самоорганізації та самоконтролю - засвоєних і закріплених у способах діяльності), яке лежить в основі готовності студентів до вирішення педагогічних завдань.

Питаннями, пов'язаними з розкриттям суті навчальних задач, які $\epsilon$ основою проблемного навчання, їх навчаючим та розвиваючим характером, займалися багато психологів і дидактів (В.В.Давидов, Д.Б. Ельконін, Н. Ізвольський, П. Ф. Каптерев, Л. М. Павська, М. М. Скаткін та ін.). Проте, аналіз сучасних досліджень свідчить про відсутність робіт, в яких би розглядалися можливості проблемного навчання під час фрормування у студентів-майбутніх вчителів іноземної мови дослідницьких умінь.

На початковому етапі використання елементів проблемного навчання під час вивчення студентами іноземної мови навчаючі дії викладача превалюють. Однак вони обов'язково спрямовані на формування в студентів різноманітних навчальних умінь - умінь самостійної пізнавальної діяльності. Поступово частка "участі" викладача в сумісній діяльності зменшується, а студентів зростає. Змінюється і якість навчальних дій - дії студентів стають більш активними, творчими і самостійними, а роль викладача зводиться до керування цією діяльністю студентів. Тобто проблемна ситуація спонукає особистість до активного мислення. При цьому зміст навчальних курсів повинен виходити за межі загальноприйнятих програм, визначатися більшим рівнем узагальненості, враховувати інтереси студентів, стиль і темп засвоєння ними знання.

Ідею проблемного навчання не можна назвати новою. Найвизначніші педагоги минулого (Я. А. Коменський, Ж.-Ж. Руссо, І.Г.Песталоцці, Ф. А. Дістерверг, К. Д. Ушинський, В.О.Сухомлинський та ін.) завжди шукали шляхи використання процесу навчання для розвитку розумових зусиль і здібностей дітей та перетворення його у радісний процес особистісного пізнання.

Проблемне навчання займає неоднакове місце протягом усього навчально-виховного процесу у ВНЗ. Традиційно вважається, що оскільки вчорашні школярі недостатньо до нього підготовлені, то питома вага проблемного навчання зростає на старших курсах. Зростання ступеня проблемності проходить таким чином: 1) проблемний виклад знань викладачем в поєднанні з репродуктивною діяльністю студентів; 2) проблемний виклад в поєднанні 3 самостійною роботою студентів за зразком; 3) комбінована лекція (проблемний виклад в поєднанні з реконструктивно-варіативною діяльністю студентів); 4) комбінована лекція, в яку входить частково-пошукова діяльність студентів; 5) створення проблемних ситуацій викладачем і навчально-дослідна 
робота студентів.

Послідовне ускладнення завдань проблемного характеру повинно забезпечити просування студентів від низького рівня дослідницьких умінь до більш високого. Система проблемного навчання, яка б охоплювала весь навчально-виховний процес, ще недостатньо розроблена у практиці ВНЗ. Основна вимога до проблемного навчання у ВН3, як зазначає О. М. Матюшкін, - це те, що воно повинно бути реалізоване в усій системі навчальної роботи студентів. Зокрема, виходячи з того, що поза особистою діяльністю проблемна ситуація не створюється, О.М. Матюшкін пропонує використати систему теоретичних (філософського спрямування) та практичних завдань (задач), виконання яких передує засвоєнню нових знань і приводить до виникнення пізнавальної потреби в засвоєнні знань [4].

Процес діяльності студентів в ході проблемного навчання має складний характер. Упродовж багатьох років він докладно вивчається психологами і методистами, але донині його сутність залишається однією 3 головних тем наукових дискусій. Психологи, педагоги та методисти розглядають діяльність 3 вирішення проблем з різних поглядів.

1.3 метою вивчення індивідуальних особливостей, для виявлення здібностей, рівня розвитку мислення (образного або логічного), уяви, пам'яті конкретної особистості.

2. Для дослідження загальних закономірностей мислення в процесі вирішення проблем певного типу. У педагогічній психології за допомогою цього методу знаходять структуру і особливості діяльності суб'єкта в процесі розв'язування задач і на цій основі дають певні рекомендації для організації цієї діяльності.

Базуючись на певних теоретичних положеннях, зокрема на теорії задач, будується ідеальна діяльність в процесі вирішення проблем. Подальше експериментальне фрормування такої діяльності у студентів дає змогу встановити, наскільки ці теоретичні положення правильні. Цей підхід автори [5, c.58] називають нормативним. Тобто розглядається, якою повинна бути діяльність суб'єкта, тому що те, якою вона буде насправді, залежить від дуже великої кількості обставин як загальних (яку він отримав освіту, які в нього особистісні особливості, які прийоми і методи роботи він засвоїв тощо), так і часткових (який настрій суб'єкта в конкретний момент, в яких умовах він перебуває, якими мотивами керується у вирішенні певного завдання тощо).

Зрозуміло, що для того, щоб сприяти найефективнішому фрормуванню дослідницьких умінь у майбутнього вчителя іноземної мови, діяльність викладача повинна базуватися на принципах гуманізму, толерантного ставлення до особистості. В контексті сказаного варто зупинитися на ідеї особистісно орієнтованого навчання та його можливостях у питанні реалізації проблемності під час фрормування дослідницьких умінь майбутнього вчителя іноземної мови.

Однією з головних цінностей майбутнього педагога стає творча активність, а, відповідно, найефективнішим методом формування дослідницьких умінь в студентів - майбутніх учителів іноземної мови, на нашу думку, стає раціональне використання елементів проблемно-пошукового навчання у всіх фрормах вузівської навчальної роботи: лекціях, семінарах, практичних заняттях, 
педагогічній практиці, курсових і дипломних роботах та ін.

Однією з умов фрормування дослідницьких умінь майбутніх учителів іноземних мов $є$ наявність суб'єкт-суб'єктної взаємодії. Дана умова потребує постановки проблемного запитання у доступній формі. Проблема стає для студента пізнавальною проблемою, якщо вона задовольняє наступним вимогам:

- представляє пізнавальну трудність, тобто вимагає роздумів;

- викликає пізнавальний інтерес;

- спирається на колишній досвід і знання на основі апперцепції.

Високий рівень дослідницьких умінь студента, на основі наших спостережень, зовні виявляється в тому, що студент:

- викладає вивчений матеріал з іноземної мови чи з дисциплін психологопедагогічного циклу(усно і письмово), спираючись попередні знання та власні судження, умовиводи, докази, висновки;

- критично ставиться до думок інших, вимагає переконливого аргументування висловлених ким-небудь положень і цю ж вимогу рівною мірою ставить до себе;

- уміло, оригінально відповідає на питання викладача, сформульовані в нових варіантах; успішно вирішує поставлені ним навчальні завдання проблемно-пошукового характеру;

- має схильність до дослідницької роботи.

До методів проблемного навчання, що можуть бути використані під час лекції та семінарсько-практичного заняття з метою формування дослідницьких умінь майбутніх учителів іноземних мов відносимо:

1. Проблемний виклад знань. Педагог ставить проблему і сам її вирішує, демонструючи шлях наукового мислення і пошукової діяльності, показує "ембріологію знань", тобто розкриває студенту шлях їх відкриття, демонструє зразок наукового пізнання, дає можливість їм спостерігати за діалектичним рухом думки до істини, залучає їх до наукового пошуку, а студенти контролюють правдоподібність запропонованих педагогом гіпотез, переконливість доказів. У них виникають сумніви, запитання, що стосуються логіки і переконливості вирішення сформульованої педагогом проблеми.

2. Частково-пошуковий метод (або евристичний), коли викладач створює проблемну ситуацію, сам формулює проблему та привертає студентів до її вирішення. Під час реалізації цього методу педагог планує етапи пошуку, розчленовує проблемне завдання на підпроблеми, які вирішують студенти.

3. Пошуковий метод. Викладач створює проблемну ситуацію, формулює проблему, а студенти повністю самостійно ії вирішують. Цей та наступний метод можливі за умов достатньо високої підготовки студентів та самостійності мислення. Рівень запитань (ступінь аналізу, системності, узагальненості до них таким чином підвищується і набуває ознак продуктивного характеру і в дослідницькому може сягати рівня невирішених в науці (наприклад, рівня Нобелівської премії).

4. Дослідницький метод, при якому студенти за умов проблемної ситуації бачать проблему, фрормулюють та вирішують ії. На думку провідних психологів і педагогів, це найскладніший для студента метод, який вимагає виявлення їх активності, самостійності, творчих здібностей, бо “сформулювати, в чому питання, - означає вже піднятися до відомого розуміння" - зазначає 
психолог С. Рубінштейн [10, с. 39].

Отже, для розвитку здатності майбутнього вчителя іноземної мови впроваджувати дослідницькі уміння у процес навчання, необхідно оновлювати не лише зміст навчальних програм 3 усіх дисциплін, а й методики їх викладання; наполегливо впроваджувати в навчальний процес дискусійну форму проведення практичних занять; передбачати для студентів самостійний пошук причинно-наслідкових зв'язків і закономірностей суспільних процесів та явищ; проводити творчі конкурси студентських робіт.

\section{Використана література:}

1. Андрущенко В.П. Світанок Європи: Проблема формування нового учителя для об’єднаної Європи XXI століття. Київ, 2011. 1099 с.

2. Андрущенко В. П., Вовк Л. П. Історія вищої педагогічної освіти в контексті цінностей соціокультурних систем. Память століть. 2006. № 3-4.

3. Амонашвили Ш. А. Психологические основы педагогіки сотрудничества. Київ : Рад. Школа, 1991. $110 \mathrm{c}$.

4. Загальна психологія : підручник / за заг. ред. акад. С. Д. Максименка. 2-ге вид., переробл. і доп. Вінниця : Нова Книга, 2004. - 704 с.

5. Карамушка Л. М. Психологія освітнього менеджменту : навч. посібник для студентів вищ. навч. закладів. Київ : Либідь, 2004. 424 с.

6. Костюк Г. С. Навчально-виховний процес і психічний розвиток особистості. Київ, 1989. 248 с. С. 22.

7. Лозова В. І., Троцко Г. В. Теоретичні основи виховання і навчання : навчальний посібник для студентів педагогічних навчальних закладів). Харків, 1997. 338 с.

8. Матюшкин А. М. Теоретические вопросы проблемного обучения. Хрестоматия по возрастной $u$ пед. психологии. Работы советских психологов периода 1946-1980 г2. / под ред. И. И. Ильясова, В. Я. Ляудис. Москва : Изд-во Моск.ун-та, 1981. - С. 274-279.

9. Пидкасистый П. И. Педагогика. - Москва, 1997.

10. Рубинштейн С. Л. О мышлении и путях его исследования. - Москва : Человек и мир, 1958. 146 с.

11. Фридман Л. М. Педагогический опыт глазами психолога : кн. для учителя. Москва, 1987. 224 с.

12. Хуторской А. В. Педагогические средства реализации эвристического потенциала образования. Педагогика. 2009. № 3. С. 17-24.

\section{References:}

[1] Andrushchenko V.P. Svitanok Y evropy: Problema formuvannia novoho uchytelia dlia obiednanoi Y evropy K hK hl stolittia. Kyiv, 2011. $1099 \mathrm{~s}$.

[2] Andrushchenko V.P., Vovk L.P. Istoriia vyshchoi pedahohichnoi osvity $\mathrm{V}$ konteksti tsinnostei sotsiokul turnykh system. Pamiat stolit. 2006. № 3-4.

[3] Amonashvyly Sh. A. Psykholohycheskye osnovы pedahohiky sotrudnychestva. Kyiv: Rad. Shkola, 1991. $110 \mathrm{~s}$.

[4] Zahalna psykholohiia : pidruchnyk / za zah. red. akad. S. D. Maksymenka. 2-he vyd., pererobl. i dop. V innytsia : N ova K nyha, 2004. - $704 \mathrm{~s}$.

[5] KaramushkaL.M. Psykholohiia osvitnoho menedzhmentu: navch. posibnyk dlia studentiv vyshch. navch. zakladiv. K yiv : Lybid, 2004. $424 \mathrm{~s}$.

[6] Kostiuk H. S. Navchalno-vykhovnyi protses i psykhichnyi rozvytok osobystosti. K yiv, 1989. 248 s. S. 22.

[7] Lozova V. I., Trotsko H.V. Teoretychni osnovy vykhovannia i navchannia : navchalnyi posibnyk dlia studentiv pedahohichnykh navchalnykh zakladiv). K harkiv, 1997. $338 \mathrm{~s}$.

[8] Matyushkin A. M. Teoreticheskie voprosy problemnogo obucheniya. H restomatiya po vozrastnoj i ped. psihologii. Raboty sovetskih psihologov perioda 1946-1980 gg. / pod red. I. I. Ilyasova, V. Y a. Lyaudis. M oskva : Izd-vo M osk.un-ta, 1981. - S. 274-279.

[9] Pidkasistyj P. I. Pedagogika. - M oskva, 1997.

[10] Rubinshtejn S. L. 0 myshlenii i putyah ego issledovaniya. - M oskva : Chelovek i mir, 1958. $146 \mathrm{s.}$

[11] Fridman L. M. Pedagogicheskij opyt glazami psi hologa : kn. dlya uchitelya. M oskva, 1987. $224 \mathrm{~s}$. 
[12] Hutorskoj A.V. Pedagogicheskie sredstva realizacii evristicheskogo potenciala obrazovaniya. Pedagogika. 2009. № 3. S. 17-24.

\section{БИНЕЦКАЯД.И. Психолого-педагогический анализ деятельности преподавателя и студента в ходе развития исследовательских умений будущих учителей иностранного языка.}

В статье рассматриваются особенности реализации исследовательских умений в процессе подготовки будущего учителя иностранного языка и основные идеи проблемного обучения, методы и приемы, организационные формы и средства целесообразного использования учебных проблемных ситуаций, постановки и решения учебных проблем, способы предъявления их преподавателем, принятия и решения студентами проблем. Доказано, что одним из необходимых условий эффективной реализации исследовательских умений в выстем учебном заведении сотрудничество, сотрудничество преподавателя и студентов. Различные определения понятия исследовательских умений обусловливают и различную их классификацию. Уровень развития творческого потенциала у каждого педагога свой. Этот факт исключает усреднения в образовании, обусловливает необходимость личностно-ориентированного обучения, учета спеиифики профессиональной подготовки студентов, их интересов и потребностей, способностей и возможностей. Иностранный язык выступает как средство коммуникаичи, общения с представителями других наиий, следовательно в образовании продолюсает развиваться и в дальнейшем культурологический или интеркультурныий подход в обучении в рамках конщепщии "диалога культур", с целью формирования полимовнои грамотности студентов.

Одной из главных иенностей будущего педагога становится творческая активность, а, соответственно, эффективныл методом формирования исследовательских умений у студентов будущих учителей иностранного языка, по нашему мнению, становится рациональное использование элементов проблемно-поискового обучения во всех формах вузовской учебной работы: лекииях, семинарах, практических занятиях, педагогической практике, курсовых и дипломных работах и др. Одним из условий формирования исследовательских умений будущих учителей иностранных языков является наличие субъект-субъектного взаимодействия. Такое условие требует постановки проблемного вопроса в доступной форме.

Следовательно, для развития способности будущего учителя иностранного языка внедрять исследовательские умения в процесс обучения необходимо обновлять не только содержсание учебных программ по всем дисииплинам, но и методики их преподавания; настойчиво внедрять в учебньй прочесс дискуссионную форму проведения практических занятий; предусматривать для студентов самостоятельный поиск причинно-следственных связей и закономерностей общественных процессов и явлений; проводить творческие конкурсы студенческих работ.

Ключевые слова: исследовательские умения, проблемное обучение, проблема, задача, будущиий педагог, творческая активность, методы, формы, приемы.

BINETSKA D. I. Psychological-pedagogical analisis of the teacher's activity and student in the development of research life of future teachers in foreign language.

The article deals with the peculiarities of realization of research skills in the process of preparation of the future teacher of a foreign language and the main ideas of problem learning, methods and techniques, organizational forms and means of expedient use of educational problem situations, the formulation and solution of educational problems, the way of presentation by their teacher, adoption and solving problems by students. It is proved that one of the necessary conditions for the effective implementation of research skills at a higher educational institution is cooperation, cooperation between the teacher and students. Various definitions of the concept of research skills predetermine their different classification. Level of development of creative potential in every teacher of his own. This fact excludes the averaging in education, stipulates the need for personality-oriented learning, taking into account the specifics of the students' professional training, their interests and needs, abilities and capabilities. Foreign language acts as a means of communication, communication with representatives of other nations, ther efore, in education, the cultural or intercultural approach in education continues to develop in the framework of the concept of "dialogue of cultures", with the 
purpose of formation of poly-gram student literacy.

One of the main values of the future teacher is creative activity, and, accordingly, an effective method of forming research skills among students - future teachers of a foreign language, in our opinion, is the rational use of elements of problem-search training in all forms of university educational work: lectures, seminars, practical training, teaching practice, term papers and dissertations, etc. O ne of the conditions for the formation of research skills of future teachers of foreign languages $s$ is the presence of subject-subject interaction. This condition requires posing the problem in an accessible form.

Therefore, in order to develop the ability of a future teacher of a foreign language to introduce research skills into the learning process, it is necessary to update not only the content of curricula in all disciplines, but also the teaching methods; persistently introduce the discussion form of practical training into the educational process; provide for students an independent search for causal relationships and patterns of social processes and phenomena; hold creati ve contests of student work.

Keywords: research skills, problem learning, problem, problem, future teacher, creative activity, methods, forms, methods.

DOI: https://doi.org/10.31392/NZ-npu-142.2019.04

УДК 373.5.091.26:51(477)"2008/2018"

Биковський Я. Т.

\section{ПОРІВНЯЛЬНИЙ АНАЛІЗ СУЧАСНОГО СТАНУ ОСВІТНІХ РЕЗУЛЬТАТІВ УЧНІВ 3 ФІЗИКИ І МАТЕМАТИКИ: 2008-2018 РОКИ}

У статті увага зосереджена на питанні оцінювання якості освіти. Представлено порівняльний аналіз сучасного рівня освітніх результатів учнів з фізики і математики у період з 2008 р. по 2018 р. за результатами зовнішнього незалежного оиінювання (3НО).

Особлива увага приділяється аналізу змін та корелячії даних результатів в охопленні учасників тестування з фізики і математики; динаміки середнього балу; відсотку учасників тестування, які складають тест з фізики і математики на 190 і більше балів, а також тих, які його не складають.

Порівняльний аналіз даних свідчить, щэо за 10 років відбувається сильна тенденція до зменшення кількості учасників тестування як з фізики, так $i$ з математики. Також відбувається значне збільшення відсотку тих учасників, які не проходять тест 3 нО з фізики та математики. Крім иьього, збільшується відсоток робіт, які виконані дуже добре (понад 190 балів), але водночас середній бал не має чітких позитивних чи негативних тенденцій з фізики чи математики.

Важливими і тривожними є показники відсотку учасників ЗНО, що не проходять тестування з фізики і математики. Так, останні 3 роки є найгіршими як для математики, так і для фізики за цим показником, який зріс приблизно в 2 рази.

Виявлено, що учасники ЗНО з фізики та математики, в останні роки сильніме розшаровуються на дві групи: на тих, щуо знають матеріал дуже добре, i на тих, хто його знає погано.

Відповідно з таких даних можна зробити висновок про необхідність посилення уваги до навчання учнів з фізики і математики у закладах освіти.

Ключові слова: якість освіти, рівень знань, фізика, математика, зовнішне незалежне оиінювання (ЗНО), аналіз даних. 